\title{
"PERLINDUNGAN HUKUM TERHADAP ANAK ANGKAT DALAM MEMPEROLEH KEJELASAN STATUS HUKUM MELALUI PENCATATAN PENGANGKATAN ANAK" (SUATU TINJAUAN DARI PERSPEKTIF HAK ASASI MANUSIA )
}

\author{
Oleh: Jean K. Matuankotta
}

\begin{abstract}
adoptions done by a number of reasons, among others, to continue the descent, to inherit property, and to provide security of life and good future for these children. In the protection of the rights of children, especially for adopted children, then the government out of Act No. 23 of 2002 on Child Protection, Law No. 23 year 2006 about Population Administration and through the implementation of the provisions of the Indonesian Government Regulation No. 54 of 2007 on the Implementation of Child Appointment. Also make policy through a strategic plan in which the programs include Children's Recording of Appointment. Government's commitment to provide clarity to the legal status of foster children through adoption records have been be realized in the issuance of state registration of adoption deed quoted as proof of legality for a foster child.
\end{abstract}

\section{Keyword: foster child, legal status}

\section{A. LATAR BELAKANG.}

Masalah Hak Asasi Manusia bukanlah merupakan masalah baru bagi masyarakat dunia, karena isu hak asasi manusia sudah mulai dilontarkan sejak lahirnya Magna Charta di Inggris pada tahun 1215, sampai lahirnya Piagam Perserikatan Bangsa- Bangsa tentang Hak Asasi Manusia, yaitu "Universal Declaration Of Human Rights" pada tanggal 10 Desember 1948. Instrumen lain dapat ditemui dalam : Konvenan Internasional tentang Hak Sosial dan Politik serta Konvenan tentang Hak Ekonomi, Sosial dan Budaya.

Sebagai bangsa yang sangat menjunjung tinggi hak asasi warganya, maka Negara Indonesia telah merealisasikannya dalam Pembukaan Undang- Undang Dasar 1945 khususnya pada alinea ke - empat yang dijabarkan dalam pasal - pasal antara lain : pasal 27 sampai dengan pasal 31, pasal 33 dan pasal 34.
Bahwa selaku manusia, anak adalah makhluk Tuhan Yang Maha Esa yang memiliki hak asasi sejak dilahirkan, sehingga tidak ada manusia atau pihak lain yang boleh merampas hak tersebut. Hak asasi anak diakui secara universal sebagaimana tercantum dalam Piagam PBB dan Deklarasi PBB Tahun 1948 tentang Hak Asasi Manusia, Deklarasi ILO, ILO (International Labour Organisation) di Philadelphia tahun 1944, Konstitusi ILO, Deklarasi PBB tahun 1959 tentang Hak Anak, Konvensi PBB Tahun 1966 tentang Hak - hak Ekonomi, Sosial, dan Budaya dan Konvensi PBB Tahun 1989 tentang Hak Anak, Konvensi ILO No. 182 Tahun 1999 tentang pelanggaran dan Tindakan Segenap Penghapusan Bentuk- bentuk Pekerjaan Terburuk Untuk Anak ( disetujui pada Konverensi Ketenagakerjaan Internasional ke -87 tanggal 17 Juni 1999 di Jenewa ). (Koesparmono Irsan, 2002 )

Dengan demikian semua Negara di dunia secara moral dituntut untuk 
menghormati, menegakkan dan melindungi hak anak tersebut.

Pada tanggal 26 Januari 1990 di New York, Pemerintah Republik Indonesia telah menandatangani Convention On The Right Of The Child sebagai hasil sidang Majelis Umum PBB yang diterima pada tanggal 20 Nopember 1989, yang kemudian disahkan melalui Keputusan Presiden Republik Indonesia No. 36 Tahun 1990. Dengan telah disahkannya konvensi tersebut maka pemerintah terikat untuk melaksanakan secara penuh hak - hak yang tertuang dalam konvensi tersebut, yang berkaitan dengan masalah : Perlindungan terhadap anak dari kekejaman, penyalahgunaan, penelantaran dan eksploitasi, Peran serta anak dalam masyarakat, berpartisipasi dalam kehidupan bermasyarakat sesuai alam pikirnya serta Penyediaan segala kebutuhan dasar anak.

Berkaitan dengan pemenuhan hak anak maka telah dibuat berbagai peraturan perundang-undangan penunjang yakni : Undang-undang Republik Indonesia Nomor 4 Tahun 1979 yang mengatur tentang Kesejahteraan Anak, Undang-undang Republik Indonesia Nomor 3 Tahun 1997 yang mengatur tentang Pengadilan Anak, Undang-undang Republik Indonesia Nomor 39 Tahun 1999 tentang Hak Asasi Manusia (khusus pada pasal 52 sampai dengan pasal 66 yang mengatur tentang hak anak).

Adapun setiap anak berhak untuk memperoleh perlindungan bilamana diperlukan, namun juga harus diberikan kesempatan yang lebih besar untuk berpartisipasi dalam hal yang berkaitan dengan tanggungg jawab orang yang lebih tua menyangkut kehidupannya. Pasal 52 Undang-undang Republik Indonesia Nomor 39 tahun 1999 menyebutkan dalam ayat :

1) Setiap anak berhak atas perlindungan oleh orang tua, keluarga, masyarakat dan Negara.

2) Hak anak adalah hak asasi manusia dan untuk kepentingannya hak anak itu diakui dan dilindungi oleh hukum bahkan sejak dalam kandungan.
Dan pasal 53 Undang-undang Republik Indonesia Nomor 39 tahun 1999 pada ayat :

1) Setiap anak sejak dalam kandungan berhak untuk hidup, mempertahankan hidup, dan meningkatkan kehidupannya.

2) Setiap anak sejak kelahirannya berhak atas suatu nama dan status kewarganegaraan.

Mengacu pada kedua pasal ini maka adalah kewajiban Pemerintah, Negara, Orang tua, dan masyarakat untuk tidak menelantarkan dan wajib peduli terhadap hak anak tersebut, dengan berupaya melakukan legalitas status identitas anak dalam bentuk Dokumen Kutipan akta Kelahiran.

Yang menjadi persoalan adalah bagaimana nasib anak - anak yang dikategorikan sebagai anak - anak terlantar atau ditelantarkan, anak yang berada dalam asuhan keluarga yang tidak mampu (miskin) atau dalam lembaga pengasuhan anak. Pada umumnya anak-anak dengan kondisi demikian sangat rentan dengan persoalan kejelasan status hukumnya yang berkaitan dengan identitas ( nama, tanggal lahir, asal usul, kewarganegaraan ) yang dibuktikan lewat kepemilikan dokumen akta kelahiran. ( Dirjen Adminduk, 2007 )

Sesuai ketentuan pasal 34 UUD 1945 "Fakir miskin dan anak - anak terlantar dipelihara oleh Negara", maka kepada mereka, pemerintah bertanggung jawab dalam hal legalisasi statusnya. Dan khusus bagi anak-anak terlantar yang diadopsi atau diangkat oleh orang tua wali maka tanggung jawab tersebut berada pada pemerintah dan para orang tua, baik orang tua kandung ( jikalau masih ada ) dan orang tua asuh dalam mengusahakan legalitas anak angkat tersebut.

Secara khusus telah ada Undang undang Nomor 23 tahun 2002 tentang Perlindungan Anak yang mengatur tentang pertanggung jawaban orang tua, keluarga, masyarakat, pemerintah dan Negara dalam kaitannya dengan masalah identitas anak. 
Hal ini khusus tertuang dalam pasal 27 pada ayatt :

1) Identitas diri setiap anak harus diberikan sejak kelahirannya.

2) Identitas sebagaimana dimaksud pada ayat (1) dituangkan dalam akte kelahiran.

Dan pada pasal 28 ayat 1 jelas dikatakan bahwa Pembuatan akta Kelahiran menjadi tanggung jawab pemerintah yang dalam pelaksanaannya diselenggarakan serendah-rendahnya pada tingkat kelurahan / desa.

Menyangkut persoalan ini setidaknya telah terjawab dengan dikeluarkannya Undang-undang Nomor 23 tahun 2006 tentang Administrasi Kependudukan yang pada hakekatnya berisi tentang kewajiban pemerintah dalam memberikan perlindungan dan pengakuan terhadap penentuan status pribadi dan status hukum atas setiap “ Peristiwa Penting “ yang dialami oleh penduduk Indonesia (khususnya anak) yang berada di dalam dan/atau di luar wilayah Negara Kesatuan Republik Indonesia.

Selanjutnya secara teknis telah dituangkan dalam Peraturan Pemerintah Negara Republik Indonesia Nomor 54 tahun 2007 tentang Pelaksanaan pengangkatan anak, yang memberi jaminan masa depan yang baik kepada anak angkat. Merupakan milestone ( tonggak bersejarah ), yang memberikan warna baru bagi perjalanan sejarah kebijakan pemerintah mengenai pencatatan pengangkatan anak di tanah air yang selama kurang lebih 62 tahun masih menggunakan staatsblad-staatsblad peninggalan zaman Belanda.

Kenyataan membuktikan bahwa sering terjadi para orang tua angkat maupun pihak-pihak yang terlibat didalamnya (Lembaga penampungan anak dan masyarakat) mengabaikannya, anak-anak yang dikategorikan sebagai anak terlantar, bahkan anak yang sudah diadopsipun terkadang ditemui belum memiliki kejelasan status hukumnya melalui kepemilikan akta kelahiran. Ini nampak ketika anak-anak tersebut hendak masuk ke dunia pendidikan dimana sekolah menuntut adanya bukti identitas sebagai prasyarat terdaftar sebagai murid di lembaga pendidikan tersebut banyak anak yang belum memilikinya. Sementara anak dan atau anak angkat itu mempunyai hak untuk mendapatkan pendidikan untuk bekal bagi masa depannya serta berhak atas perlakuan yang baik dari pihak orang tua angkat atau oleh siapapun juga. Dengan adanya kepemilikan dokumen hukum seorang anak merasa dihargai harkat dan martabat sebagai makhluk ciptaan Tuhan.

Terkadang juga muncul persoalan pembagian warisan yang deskriminatif antara anak kandung dan anak angkat dalam suatu keluarga, sehingga berujung ke Pengadilan, yang pada akhirnya anak angkat berada dipihak yang lemah karena tidak ada bukti dokumen hukum yang menguatkan status dan kedudukannya secara sah.

Sementara itu di sisi lain, tidak adanya system pencatatan pengangkatan anak yang baik dapat memberikan kontribusi yang cukup besar pada kemungkinan terjadinya trafficking (perdagangan) anak angkat. Perlu diketahui bahwa sampai dengan saat ini, Negara Indonesia sudah termasuk dalam jaringan sindikat perdagangan bayi internasional. Bahkan selain menjadi Negara pengirim, Indonesia kini juga menjadi Negara penerima dan transit anak dari berbagai Negara lain. Dan menurut harian Kompas, Indonesia sampai sekarang masih tercatat sebagai salah satu Negara pemasok terbesar dalam perdagangan anak di seluruh Asia Tenggara. Tak kurang dari 300.000 400.000 anak dari Indonesia diperdagangkan setiap tahun, baik dengan modus adopsi illegal maupun dipaksa bekerja sebagai pekerja seks komersial.

Dengan kejadian ini, menjadikan anak angkat dalam posisi yang lemah, upaya perlindungan hukum bagi anak angkat menjadi suatu slogan saja tanpa perwujudan nyata di lapangan. Kondisi tersebut tentunya tak bisa dibiarkan, dan perlu adanya perhatian dan penanganan yang lebih serius baik dari pihak Pemerintah Daerah dalam 
mengupayakan peraturan daerah dan kebijakan khusus yang mengikat dan memberikan sanksi yang tegas bagi mereka yang tidak melaksanakan ketentuan itu. Selain upaya kerjasama antara pemerintah dan seluruh elemen masyarakat termasuk orang tua angkat dalam mengupayakan suatu perlindungan hukum bagi anak angkat.

Bertolak dari uraian diatas, maka dapat dirumuskan permasalahan penelitian sebagai berikut :

1. Apa yang menyebabkan hak - hak anak angkat untuk memperoleh kejelasan status hukum melalui pencatatan pengangkatan anak belum terpenuhi dengan baik ?

2. Upaya apa yang dilakukan pemerintah untuk melindungi hak anak angkat dalam memperoleh kejelasan status hukumnya?

\section{B. PEMBAHASAN}

\section{Konsepsi Pengangkatan Anak}

Dalam Undang-undang Republik Indonesia nomor 23 Tahun 2002, pasal 1 angka 9 dinyatakan bahwa " Anak Angkat " adalah anak yang haknya dialihkan dari lingkungan kekuasaan keluarga, orang tua, wali yang sah, atau orang lain yang bertanggung jawab atas perawatan, pendidikan, dan membesarkan anak tersebut, kedalam lingkungan keluarga orang tua angkatnya berdasarkan putusan atau penetapan pengadilan.

Sedangkan pendapat Ter Haar tentang pengangkatan anak, sebagaimana dikutip oleh Muderis menyatakan bahwa : “ dengan jalan suatu perbuatan hukum, dapatlah orang mempengaruhi pergaulan pergaulan yang berlaku sebagai ikatan biologis dan tertentu dalam kedudukan sosialnya; sebagai contoh dapat disebutkan : kawin ambil anak, atau " inlijfhuwelijk ". Kedudukan yang dimaksud membawa dua kemungkinan, yaitu : a. Sebagai anak, sebagai anggota keluarga melanjutkan keturunan, sebagai ahli waris (yuridis).

b. Sebagai anggota masyarakat (social) dan menurut tata cara adat, perbuatan pengangkatan anak itu pasti dilakukan dengan terang dan tunai. (Ter Haar, dalam Bushar Muhammad, 1981)

Pendapat Ter Haar tersebut secara jelas menyatakan bahwa seseorang anak yang telah diangkat sebagai anak angkat, melahirkan hak - hak yuridis dan sosial baik dalam aspek hukum kewarisan, kewajiban nafkah dan perlindungan anak, perkawinan, dan social kemasyarakatan.

Menurut Mahmud Syaltut bahwa setidaknya ada dua pengertian 'pengangkatan Anak'. Pertama, mengambil anak orang lain untuk diasuh dan dididik dengan penuh perhatian dan kasih sayang, tanpa diberikan status 'anak kandung' kepadanya; cuma ia diperlakukan oleh orang tua angkatnya sebagai anak sendiri, kedua, mengambil anak orang lain sebagai anak sendiri dan ia diberi status sebagai 'anak kandung' sehingga ia berhak memakai nama keturunan (nasab) orang tua angkatnya dan saling mewarisi harta peninggalan, serta hak-hak lain sebagai akibat hukum antara anak angkat dan orang tua angkatnya itu. (Aziz Dahlan, 1996)

Adapun Pelaksanaan Pengangkatan Anak di Negara Indonesia meliputi :

a. Pengangkatan anak berdasarkan adat kebiasaan setempat,

Menurut Surojo Wignyodipuro (Muderis Zaini, 2002) bahwa adopsi selama hal ini harus terang, artinya wajib dilakukan dengan upacara adat serta dengan bantuan Kepala Adat. Kedudukan hukum anak yang diangkat adalah sama dengan anak kandung daripada suami isteri yang mengangkatnya, sedangkan hubungan kekeluargaan dengan orang tua sendiri yang mengangkatnya, sedangkan hubungan kekeluargaan dengan orang tua sendiri secara adat menjadi putus. Seperti yang terjadi di daerah Gayo, Lampung, Pulau Nias dan Kalimantan. 
Sedangkan menurut Bushar Muhammad (Bushar Muhammad, 1981), bahwa tata cara adat, perbuatana adopsi itu pasti dilakukan dengan terang dan tunai. Terang artinya perbuatan hukum pengangkatan anak harus dilakukan dihadapan dan diumumkan didepan orang banyak, dengan resmi secara formal, sehingga semua orang dianggap telah mengetahui. Sedangkan kata tunai berarti bahwa perbuatan pengangkatan anak itu akan selesai seketika itu juga pada saat terjadinya acara pengangkatan anak secara terang tersebut.

Namun pengangkatan anak menurut hukum adat inipun belum memiliki kekuatan hukum sepanjang belum disahkan oleh Pengadilan. Dan menyangkut hak waris maka tiap daerah memiliki perbedaan, ada yang mengakui dan menyamakan kedudukan anak angkat dengan anak kandung sehingga berhak atas warisan dari orang tua angkat. Tetapi ada juga yang berpandangan bahwa anak angkat hanya berhak atas harta warisan peninggalan orang tua angkat melalui hibah atau pemberian atau wasiat ( sebelum orang tua angkatnya meninggal dunia ).

b. Pengangkatan anak berdasarkan peraturan perundang - undangan.

Pengertian Anak Angkat menurut Peraturan Pemerintah Republik Indonesia Nomor 54 tahun 2007 tentang Pelaksanaan Pengangkatan Anak adalah anak yang haknya dialihkan dari lingkungan kekuasaan keluarga orang tua, wali yang sah, atau orang lain yang bertanggung jawab atas perawatan, pendidikan, dan membesarkan anak tersebut, ke dalam lingkungan keluarga orang tua angkatnya berdasarkan keputusan atau penetapan pengadilan.

Sedangkan

Pengertian

Pengangkatan Anak adalah suatu perbuatan hukum yang mengalihkan seorang anak dari lingkungan kekuasaan orang tua, wali yang sah, atau orang lain yang bertanggung jawab atas perawatan, pendidikan dan membesarkan anak tersebut, ke dalam lingkungan keluarga orang tua angkat.

Pengangkatan anak berdasarkan Peraturan Perundang _ undangan mencakup pengangkatan anak secara langsung dan pengangkatan anak melalui lembaga pengasuhan anak yang dilakukan melalui penetapan pengadilan.

\section{Kebijakan Pemerintah Dalam Upaya Perlindungan Hak Anak Angkat}

Perlindungan terhadap anak-anak di Indonesia termasuk anak angkat bertujuan untuk menjamin terpenuhinya hak - hak anak tersebut demi terwujudnya anak Indonesia yang berkualitas, berakhlak mulia, dan sejahtera.

Anak angkat dan anak-anak lain pada umumnya adalah amanah dan karunia Tuhan Yang Maha Esa yang dalam dirinya melekat hak-hak sebagai anak dan harkat serta martabat sebagai manusia seutuhnya, melekat hak - hak yang perlu dihormati dan dijunjung tinggi oleh orang tua angkatnya dan masyarakat pada umumnya. Hak - hak anak angkat tersebut antara lain :

a. Berhak untuk dapat hidup, tumbuh, berkembang dan berpartisipasi secara wajar sesuai harkat dan martabat kemanusiaan, serta mendapat perlindungan dari tindakan kekerasan dan diskriminasi.

b. Berhak atas suatu nama sebagai identitas diri dan status kewarganegaraan.

c. Berhak untuk beribadah menurut agamanya, berpikir dan berekspresi sesuai dengan tingkat kecerdasan dan usianya dalam bimbingan orang tua.

d. Berhak untuk mengetahui orang tuanya, dibesarkan, dan diasuh oleh orang tuanya sendiri.

e. Dalam hal karena sesuatu sebab orang tuanya tidak dapat menjamin tumbuh kembang anak, atau anak dalam keadaan terlantar, maka anak tersebut berhak diasuh atau diangkat sebagai anak asuh 
atau anak angkat oleh orang lain sesuai dengan ketentuan peraturan perundang undangan yang berlaku.

f. Berhak memperoleh pelayanan kesehatan dan jaminan sosial sesuai dengan kebutuhan fisik, mental, spiritual dan social.

g. Berhak memperoleh pendidikan dan pengajaran dalam rangka pengembangan pribadinya dan tingkat kecerdasannya sesuai dengan minat dan bakatnya.

h. Setiap anak selama dalam pengasuhan orang tua, wali atau pihak lain manapun yang bertanggung jawab atas pengasuhan, berhak mendapat perlindungan dari perlakuan diskriminasi, eksploitasi baik ekonomi maupun aseksual, penelantaran, kekejaman, kekerasan penganiayaan, ketidakadilan serta perlakuan salah lainnya.

Mengurus masa depan anak adalah sama dengan mengurus dan menyelamatkan masa depan bangsa dan Negara Indonesia. Oleh karena itu, ketentuan yang mengatur tentang kewajiban dan tanggung jawab terhadap pengelolaan dan perlindungan anak angkat di Indonesia menjadi sangat penting. Komitmen pemerintah untuk memberikan perlindungan terhadap anak telah ditindaklanjuti dengan disahkannya Undangundang republik Indonesia Nomor 2003 tahun 2002 tentang Perlindungan Anak sebagaimana yang diatur pada Bab IV mulai pasal 20 sampai dengan pasal 26, menyangkut berbagai upaya yang dilakukan dalam rangka perlindungan, pemenuhan hak-hak dan peningkatan kesejahteraan anak. Salah satu solusi untuk menangani permasalahan anak dimaksud yaitu dengan memberi kesempatan bagi orang tua yang mampu untuk melaksanakan pengangkatan anak. Namun dalam Undang-undang ini persoalan anak angkat hanya dibahas dari segi definisi anak angkat dan tata cara pengangkatan anak serta sanksi bagi pelanggaran prosedur pengangkatan anak dan tidak ada pembahasan khusus mengenai persoalan pencatatan anak angkat.
Sejak Negara Indonesia merdeka tahun 1945, baru tahun 2006 dengan diberlakukannya UU No. 23 tahun 2006 tentang Administrasi Kependudukan yang dituangkan dalam ketentuan teknis pelaksanaannya lewat Peraturan Pemerintah Republik Indonesia Nomor 54 Tahun 2007 tentang Pelaksanaan Pengangkatan Anak, setidak-tidaknya telah dapat menjawab kebutuhan dan hak anak angkat serta dijadikan sebagai payung hukum.

Adapun sebelum pemberlakuan Undang-undang nomor 23 tahun 2006 tentang Administrasi Kependudukan, maka kebijakan mengenai pencatatan pengangkatan anak pada akta kelahiran, digolongkan berdasarkan Staatsblad peninggalan Belanda yaitu :

a. Staatsblad 1849 No. 136 untuk pencatatan sipil golongan Eropa.

b. Staatsblad 1917 No. 129 untuk pencatatan sipil golongan Tionghoa.

c. Staatsblad 1920 No. 751 untuk pencatatan sipil golongan pribumi non Kristen.

d. Staatsblad 1933 No. 74 untuk pencatatan sipil golongan pribumi Kristen.

Persoalannya, penggunaan keempat Staatsblad ini sudah tidak kontekstual lagi dalam upaya menjawab persoalan pencatatan pengangkatan anak di tanah air, karena pembagian pencatatan pengangkatan anak berdasarkan golongan, agama, dan ras justru bersifat diskriminasi.

Upaya pemerintah untuk melindungi hak anak angkat untuk tercatat, dan upaya mengurangi kemungkinan terjadinya trafficking (perdagangan) anak maka kerja keras pemerintah tak berhenti hanya sebatas melahirkan Peraturan Perundang - undangan dan peraturan pelaksanaannya tetapi juga dalam tataran pelaksanaan di lapangan, pemerintah akan merealisasikan semua kebijakan itu lewat Rencana Strategis (Renstra) Pencatatan Kelahiran " Menuju 2011 Semua Anak Indonesia Tercatat ". Rencana strategis ini merupakan implementasi kebijakan nasional mengenai pencatatan kelahiran secara umum yang juga 
mencakup program - program penanganan pencatatan pengangkatan anak. Serta memperbaiki sistem pelayanan kepada masyarakat, yang terlepas dari jeratan birokrasi yang berbelit-belit tetapi sebaliknya memberikan pelayanan yang prima, dari segi kualitas dan kuantitasnya.

Bersamaan dengan itu pemerintah melakukan kerjasama dengan pihak Lembaga Swadaya Masyarakat dan organisasi-organisasi lain yang concern dalam memikirkan Masa Depan Anak angkat dan Upaya perlindungan anak angkat melalui kegiatan :

a. Penyuluhan

Bertujuan agar masyarakat mendapatkan informasi dan memahami tentang persyaratan, prosedur dan tata cara pelaksanaan pengangkatan anak.

b. Konsultasi

Bertujuan untuk membimbing dan mempersiapkan orang tua kandung dari calon orang tua angkat atau pihak lainnya agar mempunyai kesiapan dalam pelaksanaan pengangkatan anak, memberikan informasi dan motivasi untuk mengangkat anak.

c. Konseling

Bertujuan untuk membantu mengatasi masalah dalam pengangkatan anak yakni membantu memahami permasalahan dan memberikan alternativ pemecahan masalah pengangkatan anak.

d. Pendampingan

Bertujuan untuk membantu kelancaran pelaksanaan pengangkatan anak, yakni meneliti dan menganalisis permohonan pengangkatan anak, memantau perkembangan anak dalam pengasuhan orang tua anak.

e. Pelatihan

Bertujuan agar petugas memiliki kemampuan dalam proses pelaksanaan pengangkatan anak (peningkatan pengetahuan dan ketrampilan).

Serta giat melakukan pengawasan terhadap pelaksanaan pengangkatan anak, untuk mencegah pelaksanaan pengangkatan anak yang tidak sesuai dengan ketentuan peraturan perUndang-undangan, mengurangi kasus-kasus penyimpangan atau pelanggaran pengangkatan anak, serta memantau pelaksanaan pengangkatan anak.

\section{Latar Belakang Pengangkatan Anak}

Dalam prakteknya, pengangkatan anak dikalangan masyarakat Indonesia mempunyai beberapa tujuan antara lain ( Ahmad Kamil, 2008 ) :

a. Untuk meneruskan keturunan.

b. Untuk mewariskan harta.

c. Untuk memberikan jaminan hidup dan masa depan yang baik bagi anak tersebut.

d. Komersial/ Eksploitasi.

e. Sekedar untuk pancingan.

Adapun penyebab hak-hak anak angkat untuk memperoleh kejelasan status hukum melalui pencatatan pengangkatan anak belum terpenuhi dengan baik sering disebabkan karena :

a. Motivasi pengangkatan anak bukanlah semata - mata untuk kepentingan yang terbaik bagi anak, tetapi untuk komersial, perdagangan, sekedar pancingan dan setelah memperoleh anak, kemudian anak angkat disia - siakan atau ditelantarkan.

b. Rendahnya kesadaran masyarakat akan pentingnya dokumen akta kelahiran melalui pencatatan pengangkatan anak setelah memperoleh persetujuan melalui penetapan pengadilan.

c. Belum adanya Perangkat Peraturan Daerah sebagai implementasi dari pemberlakuan Peraturan Perundang _ undangan yang ada yang mengikat dan memberikan sanksi bagi mereka yang tidak melaksanakan ketentuan itu.

d. Kurangnya sosialisasi dari pemerintah terhadap pemberlakuan peraturan yang baru khususnya terhadap masyarakat yang berdomisili didaerah pedesaan tentang hal - hal yang berkaitan dengan Pengangkatan Anak.

e. Bentuk pelayanan yang terikat oleh birokrasi yang berbelit - belitpun menyebabkan masyarakat menjadi malas 
untuk melakukan pengurusan permohonan pengangkatan anak di Pengadilan Negeri dan pencatatan pengangkatan anak di Kantor Catatan Sipil.

\section{Perlindungan Hak Anak Angkat Melalui Pencatatan Pengangkatan Anak}

Berdasarkan Konvensi Hak Anak Tahun 1989, adalah hak anak untuk mendapatkan nama, identitas, dan kewarganegaraan melalui pencatatan kelahiran. Sama halnya dengan pencatatan kelahiran, maka pencatatan pengangkatan anak dalam dimensi hukum, merupakan perlindungan untuk anak.

Negara dan pemerintah berkewajiban dan bertanggung jawab menghormati dan menjamin hak asasi setiap anak tanpa membedakan suku, agama, ras, golongan, jenis kelamin, etnik budaya dan bahasa, status hukum anak, urutan kelahiran anak, dan kondisi fisik dan atau mental. Selain itu Negara dan pemerintah juga berkewajiban dan bertanggung jawab memberikan dukungan sarana dan prasarana dalam penyelenggaraan perlindungan anak serta melakukan pengawasan terhadap kegiatan dimaksud.

Berkaitan dengan hal tersebut maka, pengangkatan anak merupakan salah satu dari peristiwa penting untuk dicatat dalam register pencatatan sipil. Yang dimaksudkan dengan Peristiwa Penting menurut pasal 1 angka 17 Undang-undang RI Nomor 23 tahun 2006 tentang administrasi kependudukan adalah kejadian yang dialami oleh seseorang meliputi kelahiran, kematian, lahir mati, perceraian, pengakuan anak, pengesahan anak, pengangkatan anak, perubahan nama dan perubahan status kewarganegaraan. Sedangkan pasal 1 ayat 7 memberikan pengertian bahwa yang dimaksud Instansi Pelaksana adalah perangkat kabupaten/kota yang bertanggung jawab dan berwenang dalam urusan
Administrasi Kependudukan. Pengertian Pencatatan Sipil menurut pasal 1 angka 15 adalah : pencatatan peristiwa penting yang dialami oleh seseorang dalam register catatan sipil oleh unit kerja yang mengelola pendaftaran penduduk dan pencatatan sipil.

Khusus menyangkut pencatatan pengangkatan anak, harus dibuktikan dengan salinan persetujuan dari pengadilan negeri yaitu penetapan pengadilan (khusus bagi non muslim) dan Penetapan Pengadilan Agama (khusus bagi yang muslim). Sebagai dasar untuk dibuat catatan pinggir pada kutipan akta kelahiran anak angkat tersebut. Dengan demikian anak angkat tidak memiliki dua kutipan akta kelahiran, tetapi hanya satu dengan tambahan catatan pinggir yang merupakan catatan mengenai perubahan status atas terjadinya peristiwa penting dalam bentuk catatan yang diletakkan pada bagian pinggir akta atau pada bagian akta yang memungkinkan (dihalaman/bagian muka atau belakang akta) oleh Pejabat Pencatat Sipil.

Inti dari penjelasan diatas bahwa Pemerintah bertanggung jawab dalam perlindungan terhadap hak anak angkat melalui Pencatatan pengangkatan anak. Orang tua angkat diharapkan mencatatkan pengangkatan anak, yang sudah mendapatkan penetapan pengadilan, yang kemudian dalam dimensi pencatatn sipil berupa pembuatan catatan pinggir di Kutipan Akta Kelahiran. Catatan pinggir pada kutipan akta kelahiran merupakan bukti legal bagi status perdata anak angkat. Diharapkan pemerintah dapat mengimplementasikan pemberlakuan Undang-undang Nomor 23 tahun 2006 tentang Administrasi Kependudukan dan Peraturan Pemerintah Republik Indonesia Nomor 54 tahun 2007 tentang Pengangkatan Anak melalui Rancangan Peraturan Daeerah sehingga lebih menyentuh kebutuhan anak angkat dan orang tua angkat di Provinsi Maluku khususnya di Pemerintah Kota Ambon melaui instansi pelaksana yakni Dinas Kependudukan dan Catatan Sipil yang 
berwenang melakukan pencatatan dan penerbitan dokumen akta pencatatan sipil.

Peran serta dan kerjasama antara pemerintah dan Lembaga Swadaya Masyarakat yang peduli terhadap permasalahan anak dalam turut memberikan pemahaman melalui berbagai forum peduli anak tentang pentingnya pemberian status hukum bagi anak angkat, juga upaya peningkatan kesadaran orang tua angkat dan masyarakat melaui konseling, sosialisasi dan penyuluhan serta berbagai kegiatan lainnya diharapkan dapat menjadi solusi penyelesaian masalah perlindungan hukum anak angkat berkaitan dengan pemberian status hukumnya di Provinsi Maluku khususnya di Kota Ambon.

\section{P E N U T U P}

\section{Kesimpulan}

Dari uraian tersebut diatas dapat disimpulkan hal-hal sebagai berikut :

a. Anak merupakan amanah Allah yang patut dijaga dan dilindungi karena dalam diri anak melekat harkat dan martabat dan hak-hak sebagai manusia yang harus dijunjung tinggi. Karenanya perlindungan terhadap hak - hak anak angkat patut diutamakan demi kelangsungan hidup yang layak dan masa depan yang baik bagi anak.

b. Upaya pemerintah dalam perlindungan hak anak khususnya bagi anak angkat Nampak dengan dikeluarkannya Undangundang Nomor 23 tahun 2002 tentang Perlindungan Anak, Undang-undang Nomor 23 tahun 2006 tentang Administrasi Kependudukan dan mealui ketentuan pelaksanaan yakni Peraturan Pemerintah Republik Indonesia Nomor 54 tahun 2007 tentang Pelaksanaan Pengangkatan Anak. Juga membuat kebijakan melalui Renstra yang didalamnya mencakup program-program Pencatatan Pengangkatan Anak. c. Komitmen pemerintah untuk memberikan kejelasan status hukum bagi anak angkat melalui pencatatan pengangkatan anak telah diwujud nyatakan dalam penerbitan kutipan akta pencatatan pengangkatan anak sebagai bukti legalitas bagi seorang anak angkat.

\section{Saran}

a. Perlu adanya Peraturan Daerah yang mengatur secara teknis masalah Pengangkatan anak angkat serta sanksi yang tegas.

b. Perlu adanya kerjasama yang baik antara pemerintah dan masyarakat melalui kegiatan penyuluhan, konseling dan pendampingan dalam rangka peningkatan pemahaman tentang persyaratan, prosedur dan tata cara pelaksanaan pengangkatan anak.

c. Dalam rangka mewujudkan Rencana Strategis pemerintah yakni "Menuju 2011 Semua Anak Indonesia Tercatat", maka adalah kewajiban dan tanggung jawab pemerintah untuk melakukan pembebasan biaya administrasi sesuai dengan pasal 28 (3) Undang-undang Nomor 23 tahun 2002 tentang Perlindungan Anak.

d. Agar tidak terjadi penyimpangan dan pelanggaran dalam pengangkatan anak maka perlu adanya kerjasama antara pemerintah dan seluruh elemen masyarakat untuk melakukan pengawasan secara intensif.

e. Dukungan dan partisipasi serta kesadaran yang tinggi dari pihak orang tua menjadi salah satu faktor yang penting sebagai penentu masa depan anak angkat dalam pemenuhan hak - haknya melalui penyiapan dokumen hukum pertanda sah nya kedudukan dan statusnya dalam keluarga angkat. 


\section{DAFTAR PUSTAKA}

Agustinus Amer dkk, 1999, Hak - Hak asasi manusia Edisi Kedua, Penerbit Lembaga Administrasi Negara Republik Indonesia, Jakarta.

Aziz Dahlan, 1996, Ensiklopedia Hukum Islam, Penerbit PT. Ichtiar Baru Van Hoeve, Jilid I, Jakarta.

Bushar Muhammad, 1981, Pokok - Pokok Hukum Adat, Penerbit Pradnya Paramitha, Jakarta.

Ditjen Adminduk, 2005, Jurnal Administrasi Kependudukan, Edisi perdana tahun 2005 Tentang Rendahnya Minat Masyarakat Terhadap Akta, Penerbit Ditjen Adminduk, Jakarta.

Ditjen Adminduk, 2005, Jurnal Administrasi Kependudukan, Edisi ketiga tahun 2005 Tentang Pendataan Penduduk Miskin, Penerbit Ditjen Adminduk, Jakarta.

Ditjen Adminduk, 2006, Jurnal Administrasi Kependudukan, Edisi ketiga tahun 2006 Tentang Perdagangan Manusia, Penerbit Ditjen Adminduk, Jakarta.

Ditjen Adminduk, 2007, Jurnal Administrasi Kependudukan, Edisi keempat tahun 2007 Tentang Pengangkatan Anak, Penerbit Ditjen Adminduk, Jakarta.

H.Ahmad Kamil \& H.M. Fauzan, 2008, Hukum Perlindungan Dan Pengangkatan Anak Di Indonesia, Penerbit PT. Raja Grafindo Persada, Jakarta.

H.Andi Syamsu Alam \& H.M. Fauzan, 2008, Hukum Pengangkatan Anak Perspektif Islam,
Penerbit Kencana Prenada Media Group, Jakarta.

Ifdhal Kasim dan Johanes Da Masenus Arus, 2001, Hak Ekonomi, Sosial, Budaya, Esai - Esai Pilihan Buku 2, Penerbit Lembaga Studi dan Advokasi masyarakat, Jakarta.

Koespramono Irsan, 1998, Hak asasi Manusia dan Hukum, Penerbit Perguruan Tinggi Ilmu Kepolisian, Jakarta.

Muderis Zaini, 2002, Adopsi Suatu Tinjauan Dari Tiga Sistem Hukum, Penerbit Sinar Grafika, Jakarta.

Musthofa Sy, 2008, Pengangkatan Anak Kewenangan Pengadilan Agama, Penerbit Media Grafika 77, Jakarta.

Biro Kesejahteraan Rakyat Setda Maluku, 2007, Profil Anak Maluku 2006, Penerbit Biro Kesra Setda Maluku, Ambon.

Pusat Studi HAM Universitas Islam Indonesia, 2007, Mengurai Kompleksitas HAM ( Kajian Multi Perspektif ), Penerbit Pusat Studi HAM Universitas Islam Indonesia, Jogjakarta.

Romli Antasasmita, 2001, Reformasi Hukum, Hak Asasi manusia Dan Penegakan Hukum, Penerbit Mandar Maju, Bandung.

United Nations, 1998, Buku Panduan tentang Sistem Pencatatan Sipil dan Statistik Vital, Penerbit PT. Citra Grafika Pratama, Jakarta. 